\title{
POTENSI SENYAWA METABOLIT SEKUNDER INFUSUM DAUN DURIAN (Durio zibethinus) TERHADAP KELULUSHIDUPAN IKAN NILA (Oreochromis niloticus) PADA TRANSPORTASI IKAN HIDUP SISTEM KERING
}

\section{THE SECONDARY METABOLITES POTENTIAL OF INFUSUM DURIAN'S (Durio zibethinus) LEAVES EFFECT TO SURVIVAL RATE OF NILA (Oreochromis niloticus) ON THE LIVEFISH DRY TRANSPORT SYSTEM}

\author{
Muhammad Sholihul Abid, Endang Dewi Masithah dan Prayogo \\ Fakultas Perikanan dan Kelautan Universitas Airlangga \\ Kampus C Mulyorejo - Surabaya, 60115 Telp. 031-5911451
}

\begin{abstract}
Nila (Oreochromis niloticus) is one of the leading commodity and each year will always be increased in both local and export markets. It's in line and will continue to grow due to the tendency of shifting market demand for commodities is of the dead form of fish (frozen) or other processed into a form of life, especially for the needs of breeders on commodity stocks. One of the latest post-harvest technologies that can be applied in the handling of live fish is a fish transport system in the dry media without use of water as a medium of transport with the use of anesthesia using plants that naturally contain active compounds that have the potential as a anesthesia drugs.

This study aimed to determine the length of time different fish living on the transportation system with particular concentration infusum dried leaves of durian (Durio zibethinus) effect on the survival rate of nila (O. niloticus). Methods of this study is an experiment with three replications with different concentration intervals. It consisted of a preliminary study to determine the potential infusum durian leaves as anesthesia and primary research material as a form of media applications on the system dry. This study was conducted at the Laboratory of the Faculty of Fisheries and Marine Airlangga University.

The results showed that the effective concentration of durian leaves infusum used to transport test was $4100 \mathrm{ppm}$ with an average induction time is 40 minutes and recovery time is 48 minutes. Durian leaves infusum use in nila with $4100 \mathrm{ppm}$ concentration able to achieve the level of survival and long transportation times in a row $100 \%, 0 \mathrm{~h}, 88.89 \% ; 2 \mathrm{~h}, 22.22 \% ; 4 \mathrm{~h}, 0 \% ; 6 \mathrm{~h}$, and $0 \%, 8 \mathrm{~h}$ on media packaging live fish without water.
\end{abstract}

Keywords : Nila, Leaves Durian Infusum, Survival rate

\section{Pendahuluan \\ Ikan nila merupakan salah satu} komoditas unggulan dan tiap tahunnya akan selalu meningkat baik pada pasar lokal maupun ekspor (Kementrian Kelautan dan Perikanan (KKP), 2012). Peningkatan ini sejalan dan akan terus bertambah akibat terjadinya kecenderungan pergeseran permintaan pasar untuk komoditas perikanan yaitu dari bentuk mati (beku) atau olahan lain ke bentuk hidup terutama untuk kebutuhan stok indukan pada komoditas unggulan (Dobsikova,2009).

Penanganan dalam sistem transportasi diperlukan untuk menjaga tingkat kelulushidupan ikan tetap tinggi sampai tempat tujuan. Stres dan aktivitas fisik selama proses transportasi ikan dapat menyebabkan hilangnya kualitas produk, seperti mengurangi kesegaran ikan, pelunakan tekstur otot dan menurunkan kualitas hasil fillet. Akibat yang dapat ditimbulkan dari stres akan berdampak ekonomis pada hasil produksi budidaya ikan (Dobsikova,2009).

Salah satu teknologi transportasi ikan hidup adalah sistem kering yakni tanpa menggunakan media air sebagai media pengangkutan. Pada sistem ini, ikan dibuat dalam kondisi pingsan (anestesi) sehingga mampu mencapai tingkat kelulushidupan yang tinggi diluar media air. Anestesi ikan sendiri merupakan suatu tindakan yang membuat kondisi dimana tubuh ikan kehilangan kemampuan untuk merasa karena aktifitas respirasi dan metabolisme rendah, sehingga ikan akan mengalami perubahan secara fisiologis dari keadaan sadar menjadi pingsan (Sufianto, 2008).

Penggunaan bahan anestesi berupa zat anestesi yang diberikan pada biotaumumnya bekerja melalui impuls syaraf dengan menghambat pengiriman ion natrium melalui gerbang ion natrium selektif pada membran syaraf sehingga menurunkan tingkat metabolisme (Stoskopf, 
1993). Bahan anestesi alami umumnya merupakan bahan kimia organik hasil metabolit sekunder yang terkandung dalam kebanyakan tanaman tingkat tinggi yang digunakan antara lain senyawa metabolit sekunder seperti saponin dan rotenone (Kritzon, 2003).De Padua dkk. (1978) dalam Brown (1997) dari hasil penelitiannya pada Durio zibethinus menyebutkan adanya kandungan tanin, saponin, lemak, kalsium oksalat, dan asam format dalam daun dan batang durian kandungan saponin terdeteksi melimpah pada daun durian yang berpotensi sebagai bahan anestesi.

Penelitian ini bertujuan untuk mengetahui lama waktu yang berbeda pada transportasi ikan hidup sistem kering dengan konsentrasi tertentu infusum daun durian (Durio zibethinus) berpengaruh pada tingkat kelulushidupan ikan nila (Oreochromis niloticus). Selanjutnya, dari penelitian ini diharapkan dapat memberikan informasi ilmiah terhadap mahasiswa, pembudidaya ikan nila(Oreochromis niloticus) dan masyarakat pada umumnya tentang efektifitas pemberian infusum daun durian (Durio zibethinus)sebagai bahan anestesi pada simulasi transportasi ikan nila(Oreochromis niloticus). Selain itu, untuk mengetahui konsentrasi pemberian infusum daun durian (Durio zibethinus)yang optimal sebagai bahan anestesi ikan.

\section{Materi dan Metode}

Penelitian ini dilaksanakan di Laboratorium Fakultas Perikanan dan Kelautan Universitas Airlangga Surabaya. Penelitian ini dilaksanakan pada bulan Juli-Agustus 2013. Materi penelitian meliputi peralatan dan bahan penelitian. Peralatan yang digunakan dalam penelitian ini antara lain thermometer, stop watch, styrofoam, pisau, blender (homogenizer), timbangan analitik, botol 1 liter, aquarium, aerator, kain kasa dan kain blacu.Bahan yang digunakan meliputi aqua-demineral, serbuk gergaji, es batu, daun durian segar yang diperoleh dari beberapa petani durian di Desa Kesiman, Kecamatan Pandaan, dan ikan nila ukuran 200300 gram/ekor yang didapat di UPT Umbulan, Pasuruan.

Materi penelitian terdiri dari penelitian pendahuluan dan penelitian utama. Penelitian pendahuluan meliputi pembuatan infusum, uji nilai kisaran,dan uji efektifitas daya anestesiinfusum yang dinyatakan dengan Effective Concentration (EC-100) menurut metode ujibiologis American Public Health Association (APHA) (2005). Selanjutnya, Penelitian utama adalah percobaan perlakuan dengan konsentrasi optimal pada aplikasi transportasi sistem kering.

Uji Nilai Kisaran Konsentrasi Ambang dan Perlakuan

Tahap ini dilakukan untuk memperoleh konsentrasi ambang atas dan ambang bawah bahan anestetik infusum daun durian. Konsentrasi ambang adalah konsentrasi yang menyebabkan $95 \%$ populasi hewan uji hidup dalam waktu 48 jam (ambang bawah) dan konsentrasi yang menyebabkan hewan uji mati dalam waktu 24 jam (ambang atas). Pada penentuan konsentrasi ambang digunakan derajat konsentrasi infusum daun durian (bahan uji) yaitu 500 ppm, 1000 ppm, 2500 ppm,5000 ppm, 7500 ppm, 10000 ppm dan 0 ppmsebagai kontrol.

Setiap konsentrasi merupakan perlakuan yang diulang sebanyak 3 kali. Pengamatan dilakukan pada jam ke- 24 dan 48 , dihitung mulai bahan uji dimasukkan dalam wadah uji, setiap wadah percobaan dimasukkan 3 ekor ikan nila kedalam 10 liter. Selama percobaan ikan nila tidak diberi pakan dan air media tidak diaerasi. Ikan nila yang mati pada setiap perlakuan dicatat dan dikeluarkan dari wadah percobaan. Dosis perlakuan pada uji daya anestetik infusum daun durian ditentukan dalam interval logaritmik yang diperoleh dengan rumus menurut $\operatorname{APHA}(2005)$ :

$$
\begin{aligned}
& \log \frac{N}{n}=k\left(\log \frac{a}{n}\right) \\
& \frac{a}{n}=\frac{b}{a}=\frac{e}{b}=\frac{a}{e}=\frac{a}{d}=\frac{N}{a}
\end{aligned}
$$

Keterangan :

$\mathrm{N}=$ konsentrasi ambang atas

$\mathrm{n}=$ konsentrasi ambang bawah

$\mathrm{k}=$ jumlah konsentrasi yang diuji

$\mathrm{a}=$ konsentrasi terkecil dalam deret yang ditentukan

Melalui persamaan (1) dapat dihitung nilai konsentrasi terkecil. Selanjutnya dapat dihitung berturut-turut konsentrasi b, c, d dan e dengan menggunakan persamaan (2).

Pengujian Daya Anestesi

Penentuan daya anestesi infusum daun durian dinyatakan dengan nilai EC-100 (Effective Concentration), yaitu waktu yang diperlukan untuk memingsankan $100 \%$ hewan uji pada masing-masing konsentrasi perlakuan. Perlakuan yang diberikan ada 6 dengan 3 kali ulangan pada 3 ekor ikan nila dalam 10 liter air untuk setiap wadah uji. Selama percobaan hewan uji dipuasakan dan air media tidak diaerasi. Ikan nila yang pingsan ditunjukkan dengan keadaan diam atau tenang, posisi tubuh tetap stabil di dasar media air, operkulum dan 
mulut bergerak lamban, bila disentuh tidak banyak memberikan perlawanan. Pengamatan dilakukan setiap saat dan dicatat secara akumulatif pada menit ke-0, 15, 30, 45 dan 60 . Setelah semua ikan nila pingsan, dipindahkan ke dalam media air bersih yang beraerasi untuk mengetahui waktu pulih sadar.

Pengamatan Parameter Kualitas Air Media Uji

Pengamatan kualitas air dilakukan sebelum perlakuan dan setelah pemberian infusum selama proses anestesi pada uji pendahuluan. Parameter yang diukur adalah DO, $\mathrm{pH}$, salinitas dan suhu.

Penelitian Utama

Percobaan ini dimaksudkan untuk mengetahui ketahanan ikan nila di dalammedia bukan air setelah diimotilisasikan dengan infusum daun durian. Konsentrasi infusum yang digunakan diperoleh dari hasil pengujian pendahuluan sebelumnya pada konsentrasi yang menyebabkan ikan pingsan $100 \%$ dalam waktu tertentu. Ikan nila pingsan dikemas dalam media serbuk gergaji dingin dengan suhu awal $14^{\circ} \mathrm{C}$ dan dilakukan pra transportasi ikan selama 0,2 , 4, 6 dan 8 jam.

Pengemasan dilakukan sebagai berikut: kedalam dasar kemasan kotak styrofoam diletakkan hancuran es yang telah dibungkus kantong plastik secara merata, kemudian serbuk gergaji dingin diletakkan diatas es dengan ketebalan $7 \mathrm{~cm}$ secara merata. Ikan yang telah pingsan terlebih dahulu dibungkus kain blacu kemudian dimasukkan kedalam serbuk gergaji dengan posisi tegak, setelah itu ditambahkan serbuk gergaji diatasnya, kotak ditutup rapat dan direkatkan dengan lakban, suhu diamati dengan memasukkan termometer pada lubang yang telah dimodifikasi pada kotak styrofoam. Kemasan dibongkar selama waktu kemas 0, 2, 4, 6 dan 8 jam, kemudian ikan disadarkan.
Penyadaran dilakukan dengan memasukkan ikan ke aquarium yang cukup aerasi, suhu akuarium penyadaran disesuaikan dengan habitat ikan nila $26^{\circ}-28^{\circ} \mathrm{C}$. Presentase kelulushidupan dihitung dengan rumus :

$\%$ Ikan hidup $=$

$\frac{\text { Jwmilah ikan hidup hetika penyegaran }}{\text { fumiah ikan setelah pembongharan }} \times 100 \%$

\section{Analisis Data}

Parameter yang diamati pada penelitian utama adalah tingkat kelulushidupan yang diamati melalui jumlah presentase jumlah ikan yang hidup ketika penyegaran dibanding jumlah ikan setelah pembongkaran. Analisis data yang digunakan pada metode eksperimental atau percobaan pada penelitian utama dianalisa menggunakan uji anava 1 faktor.

\section{Hasil dan Pembahasan}

Penentuan daya anestesi infusum daun durian menggunakan metode uji nilai kisaran berdasarkan standard metode uji toksisitas APHA (2005), untuk mengetahui aktivitas bahan anestesi yang digunakan dengan memperoleh konsentrasi ambang atas dan ambang bawah. Berdasarkan Tabel 1 dapat diketahui nilai ambang atas pada konsentrasi 5000 ppm sedangkan ambang bawah pada konsentrasi 1000 ppm. Kemudian dari data ambang atas dan bawah pada uji nilai kisaran melalui perhitungan pada persamaan 1 dan persamaan 2 dengan rumus logaritmik uji konsentrasi ambang didapat interval konsentrasi yang digunakan untuk uji efektivitas infusum daun durian dengan deret konsentrasi 1300 ppm, 1700 ppm, 2300 ppm, 3100 ppm, 4100 ppm, dan 5100 ppm.

Tabel 1. Hasil uji nilai kisaran proses anestesi ikan nila

\begin{tabular}{|c|c|c|c|c|c|c|c|c|c|c|c|}
\hline \multirow{3}{*}{$\begin{array}{l}\text { Konsentrasi } \\
\quad(\mathrm{ppm})\end{array}$} & \multicolumn{5}{|c|}{ Letal 24 jam } & \multicolumn{6}{|c|}{ Letal 48 jam } \\
\hline & \multicolumn{3}{|c|}{ Ulangan ke- } & \multirow{2}{*}{ Jml } & \multirow{2}{*}{$\begin{array}{c}\text { Mort. } \\
(\%)\end{array}$} & \multirow{2}{*}{$\begin{array}{c}\text { Konsentrasi } \\
(\mathrm{ppm})\end{array}$} & \multicolumn{3}{|c|}{ Ulangan ke - } & \multirow{2}{*}{ Jml } & \multirow{2}{*}{$\begin{array}{l}\text { Mort. } \\
(\%)\end{array}$} \\
\hline & 1 & 2 & 3 & & & & 1 & 2 & 3 & & \\
\hline 0 & $0 / 3$ & $0 / 3$ & $0 / 3$ & $0 / 9$ & 0 & 0 & $0 / 3$ & $0 / 3$ & $0 / 3$ & $0 / 9$ & 0 \\
\hline 500 & $0 / 3$ & $0 / 3$ & $0 / 3$ & $0 / 9$ & 0 & 500 & $0 / 3$ & $0 / 3$ & $0 / 3$ & $0 / 9$ & 0 \\
\hline 1000 & $0 / 3$ & $0 / 3$ & $0 / 3$ & $0 / 9$ & 0 & 1000 & $0 / 3$ & $0 / 3$ & $0 / 3$ & $0 / 9$ & 0 \\
\hline 2500 & $0 / 3$ & $3 / 3$ & $3 / 3$ & $6 / 9$ & 66,67 & 2500 & $3 / 3$ & $3 / 3$ & $3 / 3$ & $9 / 9$ & 100 \\
\hline 5000 & $3 / 3$ & $3 / 3$ & $3 / 3$ & $9 / 9$ & 100 & 5000 & $3 / 3$ & $3 / 3$ & $3 / 3$ & $9 / 9$ & 100 \\
\hline 7500 & $3 / 3$ & $3 / 3$ & $3 / 3$ & $9 / 9$ & 100 & 7500 & $3 / 3$ & $3 / 3$ & $3 / 3$ & $9 / 9$ & 100 \\
\hline 10000 & $3 / 3$ & $3 / 3$ & $3 / 3$ & $9 / 9$ & 100 & 10000 & $3 / 3$ & $3 / 3$ & $3 / 3$ & $9 / 9$ & 100 \\
\hline
\end{tabular}


Tabel 2. Lama waktu pingsan dan sadar ikan nila selama proses anestesi dengan konsentrasi berbeda

\begin{tabular}{|c|c|c|c|c|c|c|c|}
\hline \multirow[t]{2}{*}{ Perlakuan } & \multirow{2}{*}{$\begin{array}{l}\text { Konsentrasi (ppm) } \\
\text { dalam } 10 \mathrm{~L} \text { air }\end{array}$} & \multicolumn{3}{|c|}{$\begin{array}{l}\text { Pingsan (menit) } \\
\text { Ulangan ke - }\end{array}$} & \multicolumn{3}{|c|}{$\begin{array}{l}\text { Sadar (menit) } \\
\text { Ulangan ke - }\end{array}$} \\
\hline & & 1 & 2 & 3 & 1 & 2 & 3 \\
\hline$X_{\text {control }}$ & 0 & - & - & - & - & - & - \\
\hline$X_{1}$ & 1300 & - & - & - & - & - & - \\
\hline$X_{2}$ & 1700 & - & - & - & - & - & - \\
\hline$X_{3}$ & 2300 & - & - & - & - & - & - \\
\hline$X_{4}$ & 3100 & 52 & 58 & 47 & 30 & 35 & 42 \\
\hline$X_{5}$ & 4100 & 45 & 40 & 46 & 49 & 55 & 40 \\
\hline$X_{6}$ & 5100 & 25 & 37 & 35 & 112 & 73 & 82 \\
\hline
\end{tabular}

Keterangan : (-) waktu induksi > 60 menit atau ikan belum terindikasi pingsan.

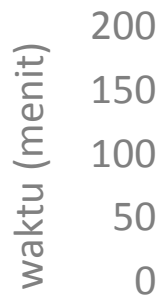

Hasil pengamatan pada Tabel 2 untuk uji efektivitas infusum daun durian sebagai bahan anestesi menggunakan metode Effective concentration (EC-100)menunjukkan bahwa penggunaan konsentrasi uji 1300 ppm, 1700 ppm, dan 2300 ppm masih belum terlihat adanya respon. Hal ini ditandai pada aktivitas ikan nila yang tetap normal selama proses anastesi berlangsung.Pada konsentrasi yang lebih tinggi yakni 3100 ppm, 4100 ppm, dan 5100 ppm terjadi perubahan tingkah laku ikan nila ditandai dengan pergerakan operkulum melambat yang diikuti lemahnya respon ikan terhadap rangsangan dari luar, dan hilangnya keseimbangan selama proses anestesi dilakukan. Pada Tabel 2 terlihat perbedaan waktu pingsan pada berbagai konsentrasi uji, adanya perbedaan konsentrasi menyebabkan perbedaan jumlah hewan uji yang pingsan dan waktu tercapainya pingsan juga berbeda (Sukarsa, 2005). Hal ini diduga bahwa semakin tingginya konsentrasi bahan uji maka semakin tinggi konsentrasi infusum daun durianyang terserap dalam jangka waktu tertentu.

Belum adanya respon ikan selama proses anestesi diduga karena terdapat kandungan senyawa aktif saponin dari hasil metabolit sekunder infusum daun durian belum mempengaruhi keseimbangan fungsi syaraf dan jaringan otak ikan nila, meskipun tidak menutup kemungkinan adanya zat aktif yang masuk kedalam tubuh melalui insang dan difusi membran (Pramono, 2002). Senyawa saponin mampu mempengaruhi keseimbangan kationik tertentu didalam otak dan terganggunya sistem syaraf akibat interaksinya dengan sel darah merah yang menyebabkan hemolisis sel sehingga berkurangnya jumlah oksigen yang berperan sebagai sumber energi pada aktivitas sel (Seeman, 1967).

Interaksi infusum daun durian pada proses anestesi ikan nila terlihat pada respon ikan yang menurun dan gerak operkulum yang melambat menurunkan tingkat respirasi ikan. Penurunan laju respirasi akan mengganggu proses metabolisme ikan, ketika tingkat metabolisme 
ikan rendah hal ini akan menyebabkan ikan tidak mampu untuk menanggapi respon dari luar akibat penurunan mekanisme kerja otak menurun akibat kekurangan oksigen dan dapat melumpuhkan sistem syaraf motorik ikan $(\mathrm{Hu}$, 2001).

Penentuan konsentrasi efektif yang digunakan pada transportasi kering menggunakan metode EC-100 dan analisa regresi linier untuk menggambarkan hubungan antara lama waktu pingsan dengan konsentrasi.Hasil analisa didapatkan persamaan linier dari hasil pengamatan pada konsentrasi 3100 ppm, 4100 ppm, dan 5100 ppm yang mampu memingsankan $100 \%$ populasi ikan nila. Persamaan regresi yang lain adalah proses sebaliknya dari ketidaksadaran akibat pembiusan yakni ikan berada dalamkeadaan siuman (sadar) setelah dipindahkan dari air yang mengandung bahan uji kedalam airtanpa perlakuan bahan uji yang diaerasi.

Model analisis varian pengaruh pemberian konsentrasi infusum daun durian sebagai bahan anestesi menggunakan program SPSS versi 16 dengan analisa regresi linier, hal ini dilakukan untuk mengetahui apakah terdapat perbedaan yang signifikan antar perlakuan dengan konsentrasi yang berbeda.Garis linier pada Gambar 1 didapat dengan memasukkan rumus regresi linier pada waktu pingsan dan waktu sadar beserta data hasil pengamatan EC-100 menggunakan software Excel versi 2013 sehingga terlihat konsentrasi optimal yang dipakai pada pengujian utama percobaan transportasi kering ikan nila adalah pada konsentrasi 4100 ppm, dengan interval antara waktu pingsan dan waktu sadar yang optimal pada nilai percobaan EC-100.
Uji statistik waktu pingsan maupun konsentrasi dengan waktu sadar dapat dilihat bahwa nilai $\mathrm{F}$ hitung lebih besar daripada $\mathrm{F}$ tabel pada selang kepercayaan $95 \%$ (F tabel = 5,59) menjelaskan terdapat perbedaan yang nyata antar tiap perlakuan pada uji EC-100. Selanjutnya untuk analisa regresi linier didapat persamaan regresi linier untuk lama waktu pingsan yakni $y=83,7-0,01 x$, dengan $y$ sebagai lama waktu pingsan dan $x$ sebagai konsentrasi yang digunakan. Sedangkan untuk lama waktu sadar digambarkan pada persamaan linier $y=$ $51,7+0,027 x$, dengan $y$ sebagai lama waktu pingsan dan $x$ sebagai konsentrasi yang digunakan.

Batas interpolasi antara konsentrasi 3100 hingga 5100 pada Gambar 1 menunjukkan rentang pengambilan data variabel bebas untuk prediksi, sehingga prediksi hanya boleh dilakukan bila suatu nilai yang digunakan sebagai input untuk variabel $x$ berada dalam rentang tersebut (Kurniawan, 2008).

\section{Parameter Kualitas Air Selama Proses Anestesi}

Hasil pengamatan pada media percobaan sebelum penambahan bahan anastesi yakni $\mathrm{pH}$ 7, suhu $28^{\circ} \mathrm{C}$, salinitas $1,00 \%$, DO $6 \mathrm{mg} / \mathrm{l}$, dan setelah penambahan bahan anestesi $\mathrm{pH} 7$, suhu $30^{\circ} \mathrm{C}$, salinitas $1,00 \%$, DO $6 \mathrm{mg} / \mathrm{l}$. Kualitas air sebelum dan setelah ditambahkan bahan anastesi tidak banyak mengalami perubahan dan masih pada batas kelayakan media untuk ikan nila. Hal ini menunjukkan bahwa diduga senyawa aktif saponin yang terkandung dalam bahan anastesi infusum daun durian mampu mempengaruhi ikan nila selama proses pembiusan, bukan karena penurunan kualitas air.

Tabel 3. Kelulushidupan ikan nila pada tranportasi ikan hidup sistem kering

\begin{tabular}{|c|c|c|c|c|}
\hline $\begin{array}{c}\text { Waktu } \\
\text { Transpotasi (jam) }\end{array}$ & Ulangan & $\begin{array}{l}\text { Jumlah } \\
\text { ikan hidup } \\
\text { (ekor) }\end{array}$ & Kelulushidupan (\%) & $\begin{array}{c}\text { Kelulushidupan rata - } \\
\text { rata }(\%)\end{array}$ \\
\hline \multirow{3}{*}{0} & 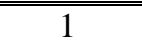 & $3 / 3$ & 100 & \multirow{3}{*}{100} \\
\hline & 2 & $3 / 3$ & 100 & \\
\hline & 3 & $3 / 3$ & 100 & \\
\hline \multirow{3}{*}{2} & 1 & $3 / 3$ & 100 & \multirow{3}{*}{88,89} \\
\hline & 2 & $3 / 3$ & 100 & \\
\hline & 3 & $2 / 3$ & 66,67 & \\
\hline \multirow{3}{*}{4} & 1 & $0 / 3$ & 0 & \multirow{3}{*}{22,22} \\
\hline & 2 & $0 / 3$ & 0 & \\
\hline & 3 & $2 / 3$ & 66,67 & \\
\hline \multirow{3}{*}{6} & 1 & $0 / 3$ & 0 & \multirow{3}{*}{0} \\
\hline & 2 & $0 / 3$ & 0 & \\
\hline & 3 & $0 / 3$ & 0 & \\
\hline \multirow{3}{*}{8} & 1 & $0 / 3$ & 0 & \multirow{3}{*}{0} \\
\hline & 2 & $0 / 3$ & 0 & \\
\hline & 3 & $0 / 3$ & 0 & \\
\hline
\end{tabular}


Berdasarkan hasil pengamatan pada uji transportasi kering pada ikan nila menggunakan infusum daun durian pada waktu kemas 0, 2, 4, 6, dan 8 jam yang terdapat pada Tabel3, diperoleh nilai kelulushidupan tertinggi pada waktu kemas 2 jam dengan rata-rata kelulushidupan sebesar $88,89 \%$ sedangkan pada waktu 4 jam hanya mencapai tingkat kelulushidupan dengan rata-rata sebesar 22,22\% dan untuk kelulushidupan terendah pada waktu 6 dan 8 jam adalah 0\%.Hasil analisa statistik menggunakan rancangan acak lengkap (RAL) dengan tiga kali ulangan pada program SPSS versi 16, dapat dikatakan dengan selang kepercayaan $95 \%$ perlakuan pemberian konsentrasi infusum daun durian sebesar 4100 ppm pada waktu yang berbeda memberikan pengaruh yang sangat nyata terhadap kelulushidupan ikan nila $\left(\mathrm{F}_{\text {hitung }}>\mathrm{F}_{\text {tabel }}\right)$.

Secara umum semakin lama waktu kemas yang dilakukan maka akan semakin menurun tingkat kelulushidupan ikan nila. Hal ini diduga karena pengaruh senyawa aktif dari bahan anestesi semakin berkurang akibat metabolisme meningkat dan kondisi kemasan selama percobaan transportasi berlangsung. Menurut Wibowo (1993) ketika bahan pembius mulai berkurang, ikan berangsur-angsur pulih kesadarannya ditandai dengan pergerakan operkulum yang mulai meningkat dan respon terhadap rangsangan luar tinggi. Ikan yang pulih sadar metabolismenya meningkat dan kebutuhan oksigen untuk respirasi juga akan meningkat, jika kebutuhan oksigen sedikit ikan akan berangsur lemas dan kemudian akan terjadi kematian.

Proses penyadaran ikan dilakukan pada media air yang telah diaerasi dengan suhu yang telah disesuaikan dengan habitat ikan nila. Respon ikan sadar pada umumnya ditandai dengan gerakan operkulum yang meningkat serta posisi ikan yang kembali stabil dan gerak sirip ikan yang kembali normal. Rata- rata ikan sadar pada menit ke-35 meskipun kondisi ikan masih terlihat lemah. Menurut Hunn dan Allen (1974) kondisi ini dimungkinkan karena sirkulasi darah mulai stabil seiring berpindahnya bahan pembius dari aliran darah ke lingkungan melalui insang, sebab jalur pemasukan dan pengeluaran bahan aktif anestesi pada ikan sebagian besar melalui insang.

Kesimpulan dari hasil analisa data mengunakan software SPSS 16 adalah lama waktu transportasi berpengaruh sangat nyata $(\mathrm{P}<0,01)$, terhadap tingkat kelulushidupan $(\mathrm{SR})$ ikan nila pada sistem transportasi kering, hal ini dapat dilihat dari nilai $F_{\text {hitung }}$ lebih besar dari $\mathrm{F}_{\text {tabel }}$ (lihat tabel $\mathrm{F}_{(0,01)} \mathrm{db} 4 ; 10$ ) atau nilai signifikan $=0,00(\mathrm{P}<0,01) \cdot$ Kesimpulan dari uji BNT dan uji Duncan terjadi penurunan tingkat kelulushidupan ikan nila pada uji coba transportasi kering yang sangat nyata $(\mathrm{P}<0,01)$ dari jam ke- 0 sampai dengan jam ke- 8 , hal ini dapat dilihat dari nila signifikan pada Uji BNT yaitu $0,00(\mathrm{P}<0,01)$ dan subset pada uji Duncan dimana terletak pada subset yang berbeda.

\section{Kesimpulan}

Hasil dari penelitian pengamatan lama waktu yang berbeda pada aplikasi transportasi ikan hidup sistem kering komoditas ikan nila dengan penggunaan bahan anestesi infusum daun durian pada tingkat kelulushidupan ikan nila dengan konsentrasi $4100 \mathrm{ppm}$ dapat disimpulakan tingkat kelulushidupan tertinggi $88,89 \%$ pada waktu pengemasan selama 2 jam, kemudian $22,22 \%$ selama waktu kemas 4 jam, dan tingkat kelulushidupan terendah sebesar $0 \%$ pada waktu kemas 6 dan 8 jam. Semakin lama waktu pengemasan maka semakin kecil tingkat kelulushidupan ikan nila pada transportasi ikan hidup sistem kering dengan bahan anestesi infusum daun durian.

Perlu ada penelitian lebih lanjut mengenai indentifikasi senyawa aktif yang terkandung dalam daun durian, dan isolasi senyawa sapogenin yang terkandung didalamnya yang berpotensi lebih besar sebagai bahan anestesi.Secara aplikasi perlu dilakukan uji coba lapangan sehingga didapat paket teknologi penanganan dan transportasi komoditi perikanan hidup untuk melengkapi komponen aplikasi transportasi ikan hidup sistem kering.

\section{Daftar Pustaka}

American Public Health Association (APHA). 2005. Standard Method for Examination of Water and Wastewater.

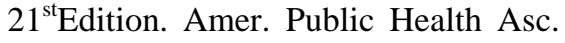
New York. p 8-10 - 8 - 151.

Brown, M. J. 1997. Durio A Bibliographic Review. International Plant Genetic Resource Institute. India. 196 p.

Dobsikova R, Svobodova Z, Blahova J, Modra H, and Velisek J. 2009. The Effect ofTransport on Biochemical and Haetological Indices of Common Carp(Cyprinus carpio L.). Journal of AnimalScience. p. 510-518.

Hu, H. 2001. Mechanisms of Anesthetic Action: Oxygen Pathway Perturbation Hypothesis. Departement of Pathology The Mount Sinai Medical Centre. New York. 17 p.

Kementerian Kelautan dan Perikanan (KKP). 2012. Laporan Akuntabilitas Kinerja 
KKP-2011. Kementerian Kelautan dan Perikanan Republik Indonesia. Jakarta. 86 hal.

Kritzon, C. 2003. Fishing With Poison. Bull. The Bulletin Of Primitive Technology. School Of North America. America. 25 p.

Kurniawan, D. 2008. Regresi Linier. RFoundation for Statistical Computing. Vienna, Austria. 17 hal.

Pramono, V. 2002. Penggunaan Ekstrak Caulerpa racemosa Sebagai Bahan Pembius pada Pra Transportasi Ikan Nila (Oreochromis niloticus) Hidup. Skripsi. Institut Pertanian Bogor. Bogor. 50 hal.

Seeman, P. 1967. Transient Holes in The Erythrocyte Membrane During Hypotonic Hemolysis and Stable in The Membrane After Lysis by Saponin and Lysolechitin. Departement of Pharmacology. Cambridge University. England. 16 p.
Stoskopf, M.K. 1993. Fish Medicine. W.B Saunder s Company. Mexico. Hal. 79 112.

Sufianto. 2008. Uji Transportasi Ikan Mas Koki (Carrasius auratus L.) Hidup Sistem Kering Dengan Perlakuan Suhu dan Penurunan Konsentrasi Oksigen. Tesis. Sekolah Pasca Sarjana. Institut Pertanian Bogor. Bogor. 119 hal.

Wibowo, S. 1993. Penerapan Teknologi Penanganan dan Transportasi Ikan Hidup di Indonesia. Sub Balai Penelitian Perikanan Laut Slipi. Jakarta. 9 hal. 